\title{
Potential research ethics violations against an indigenous tribe in Ecuador: a mixed methods approach
}

Esteban Ortiz-Prado ${ }^{1 *}\left(\mathbb{D}\right.$, Katherine Simbaña-Rivera $^{1}$, Lenin Gómez-Barreno ${ }^{1}$, Leonardo Tamariz², Alex Lister ${ }^{3}$, Juan Carlos Baca ${ }^{4}$, Alegria Norris ${ }^{5}$ and Lila Adana-Diaz ${ }^{6}$

\begin{abstract}
Background: Biomedical and ethnographic studies among indigenous people are common practice in health and geographical research. Prior health research misconduct has been documented, particularly when obtaining genetic material. The objective of this study was to crossmatch previously published data with the perceptions of the Waorani peoples about the trading of their genetic material and other biological samples.

Methods: We conducted a mixed methods study design using a tailored 15-item questionnaire in 72 participants and in-depth interviews in 55 participants belonging to 20 Waorani communities about their experiences and perceptions of participating in biomedical research projects. Additionally, we conducted a systematic review of the literature in order to crossmatch the published results of studies stating the approval of an ethics committee and individual consent within their work.

Results: A total of 40 men (60\%) and 32 women (40\%), with a mean age of $57 \pm 15$ years agreed to be interviewed for inclusion. Five main categories around the violation of good clinical practices were identified, concerning the obtention of blood samples from a recently contacted Waorani native community within the Amazonian region of Ecuador. These themes are related to the lack of adequate communication between community members and researchers as well as the voluntariness to participate in health research. Additionally, over 40 years, a total of 38 manuscripts related to the use of biological samples in Waorani indigenous people were published. The majority of the studies (68\%) did not state within their article obtaining research ethics board approval, and $71 \%$ did not report obtaining the informed consent of the participants prior to the execution of the project.

Conclusion: Clinical Research on the Waorani community in the Ecuadorian Amazon basin has been performed on several occasions. Unfortunately, the majority of these projects did not follow the appropriate ethical and professional standards in either reporting the results or fulfilling them. The results of our investigation suggest that biological material, including genetic material, has been used by researchers globally, with some omitting the minimum information required to guarantee transparency and good clinical practices. We highlight the importance of stating ethics within research to avoid breaches in research transparency.
\end{abstract}

Keywords: Consent, Research ethics board, Indigenous populations, Waorani, Ecuador

*Correspondence: e.ortizprado@gmail.com

${ }^{1}$ One Health Research Group, Faculty of Medicine, Universidad de Las

Americas, Ecuador Calle de los Colimes y Avenida De los Granados,

Quito 170137, Ecuador

Full list of author information is available at the end of the article

\section{Introduction}

The Amazon basin is home to many indigenous groups that live in a very traditional way, some of them in partial or complete isolation from the rest of the world [1-4]. Indigenous groups represent vulnerable populations 
from a research standpoint, and they often lack experience participating in research with communities being unaware of the research conducted in some cases.

Because of their lack of genetic admixture and lack of contact with the developed world, indigenous populations are unique for genetic and biomarker clinical research. Several studies have already documented research ethics violations among indigenous populations [5-13].

In 2012, the Waorani nationality, known as Nacionalidad Waorani del Ecuador (NAWE), brought to the attention the use of genetic samples to the government, to which the natives state that the samples were taken from the community without their consent [14]. The media attention and government support led to the creation of a commission to investigate these allegations. The objective of this study was to present available information on the case, which included a faceto-face field visit to the Waorani communities in the Ecuadorian Amazon region.

\section{Methods}

\section{Study aim}

The aim of this study was to conduct a systematic literature review on studies performed using biological material from Waorani natives and to analyse their perception about sample extraction and commercialization in the last 40 years.

\section{Study design}

A mixed method analysis that used a quantitative approach through the use of a closed-questions 15-items tailored questionnaire and a systematic review of the literature concerning the use of biological samples among Waorani was employed for this study. The qualitative approach included in-depth interviews among the affected population.

\section{Setting}

The study began on 2nd September 2012 with the in-situ visits to the Waorani territory. Interviews were completed on the 15th September 2012. The systematic review was finalised during early October 2019.

A total of 20 Waorani groups were visited in the three provinces that encompasses their territory in Ecuador, including the provinces of Pastaza, Sucumbios and Orellana (Fig. 1).

In order to access to the participants, the former president of the NAWE and two members of the community helped to locate the communities that were reported during the biomedical investigations.

\section{Study population}

The Waorani are the most recently contacted and partially isolated indigenous group of the Ecuadorian Amazon rainforest. The name comes from the term "Wao", which means 'people' in the Wao-Terero language. Their territory currently covers more than 670,000 hectares, recognized by the Ecuadorian State. The Waorani are currently more than 3000 people grouped in 47 family groups distributed throughout the Waorani territory and the Yasuní National Park. Their territory runs between the Napo river to the north and the Curaray river to the south (Fig. 1).

\section{Subjects recruitment and sample size}

Our sampling strategy consisted of a purposive sample strategy among the 47 Waorani groups located within their territory and included all the participants that fulfilled the inclusion criteria. 72 subjects completed the questionnaire and 55 of them agreed to be videotaped for the in-depth and personal interviews.

Twenty Waorani clans were visited per the published literature described below, obtained after reaching an agreement with the representatives of the NAWE. We focused on the older generations who were more likely to have repeated previous participation in clinical research helped by the former president of the NAWE and two members of the Waorani nationality.

\section{Ethical approval}

The Ministry of Science and Technology (Senescyt) approved this study using an ad-hoc institutional review board including a board of Waorani tribesmen from NAWE to ensure all the ethical aspects are fulfilled. The informed consent was elaborated in Spanish and verbally translated to Wao-Terero through the Waorani members of the team. Since most of the participants did not know how to write or read, a Waorani translator was used to obtain consent from all the participants.

\section{Eligibility criteria}

All subjects who were willing to contribute to the study and have completed at least 18 years of age at the time of the study were included. The subjects were relucted from the 20 communities described in the published scientific articles available after obtaining a written informed consent.

\section{Commission team}

The in-situ commission team responsible for investigating the alleged bioethical violations of the Waorani rights was led by (EO) as Team Leader, Alegria 


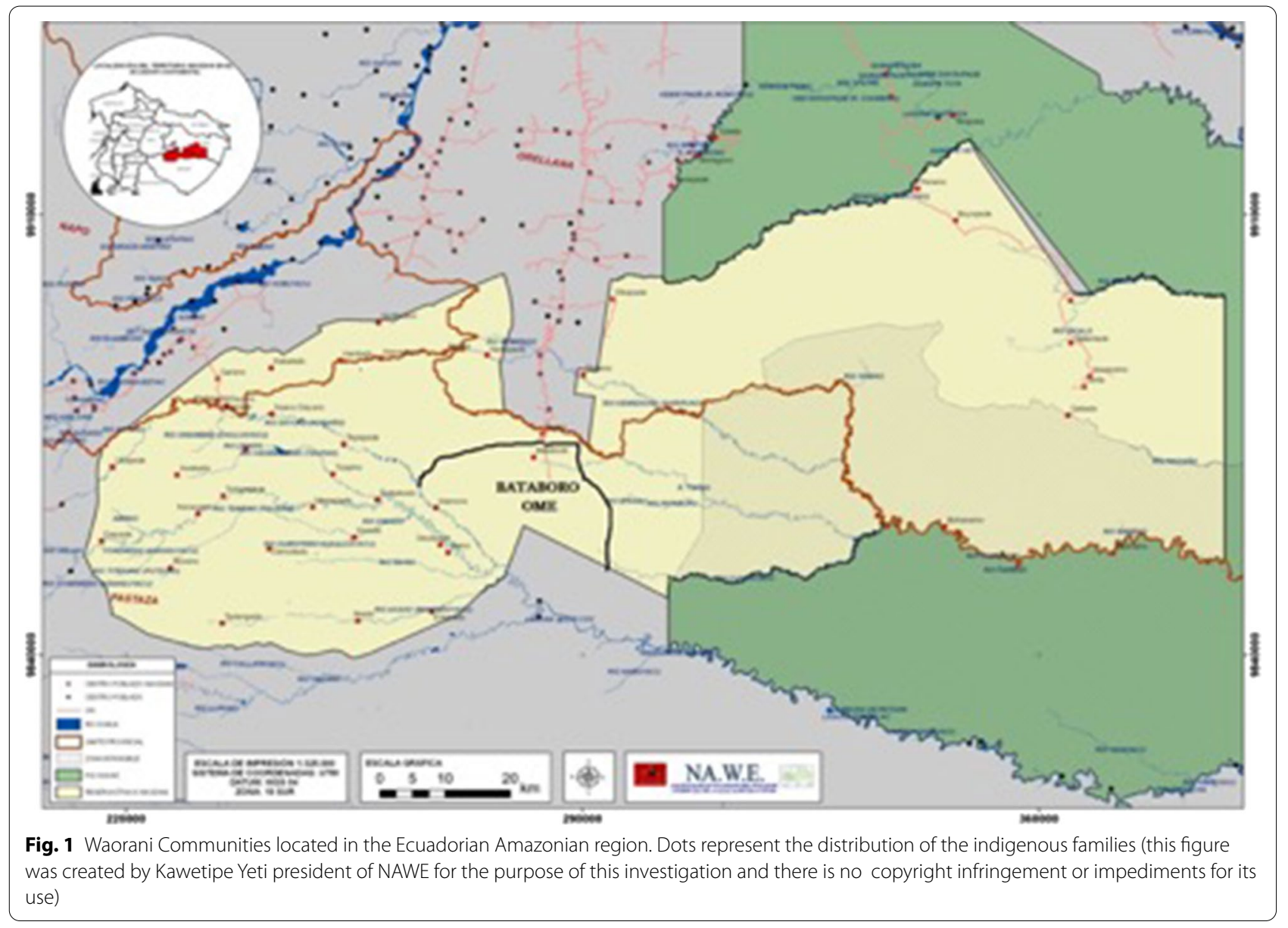

Norris (AN) and Juan Carlos Baca (JCB) as Associate Investigators and Marta Carvajal (MC) as Team lawyer.

The commission was created under the direct request of the former President of Ecuador Rafael Correa Delgado and funded by the highest authority for science and technology of Ecuador (Senescyt). The in-situ commission included the president of the Waorani communities (NAWE) Cawetipe Yeti and two other members of the tribe.

\section{Qualitative methods}

We used a qualitative approach to obtain in-depth information regarding previous experiences with research studies and biological samples collection. A videotaped interview was conducted by (EO) as the medical team leader, (JB) as the communication leader, (AN) as field expert and $(\mathrm{MC})$ as the regulatory advisor. All the faceto-face interviews and responses were translated by one of the three Waorani guides in real-time while all the information was video recorded. The interview included open-ended questions regarding Waorani experiences when blood specimens were obtained in the past. Two authors (EO and LT) evaluated each comment, with disagreements resolved by consensus.

A content analysis was performed according to the information collected in the interview [15-17]. The purpose of the analysis was to identify Waorani experiences with research through the establishment of categories drawn from their discourse. Interview testimonies were coded by the team and compared for accuracy, with characteristic elements for each category grouped for analysis [18].

\section{Quantitative methods}

We have developed a new survey (Additional file 1: Supplementary file 1) in coordination with a panel of experienced scientific researchers, NAWE representation and the staff of the commission ("Appendix"). The survey included 15 questions in the native Wao-Terero language. The domains of the survey included questions their experiences and attitudes about the use of research samples ("Appendix"). After we developed the survey, we pilot-tested it with the Waorani representatives $(n=6)$ for construct validity. 


\section{Literature review}

A systematic review of the literature of previously published studies who had collected data from one of the 20 identified Waorani communities.

The searching strategy encompassed the following databases: PubMed, Medline, Med Caribe, Ibecs, Scielo, Lilacs and ScienceDirect. The manuscripts were searched in either Spanish or English using the following terms: "Waorani", "Huaorani", "Guarani", "Auca", "Yasuní", "gen" and "genome". This review was designed to explore the groups which had conducted research on the native populations and through which scientific methodologies (Fig. 2).

\section{Statistical analysis}

Pearson's chi-square statistic was used for categorical variables and a $t$ test for continuous measures. Some continuous variables were not normally distributed, and therefore the Wilcoxon rank-sum test was used. To evaluate univariate differences, we reported the percentage of responses using the chi-square test. Analyses were performed using the statistical package SPSS (Chicago, IL), and all significance tests were two-tailed.

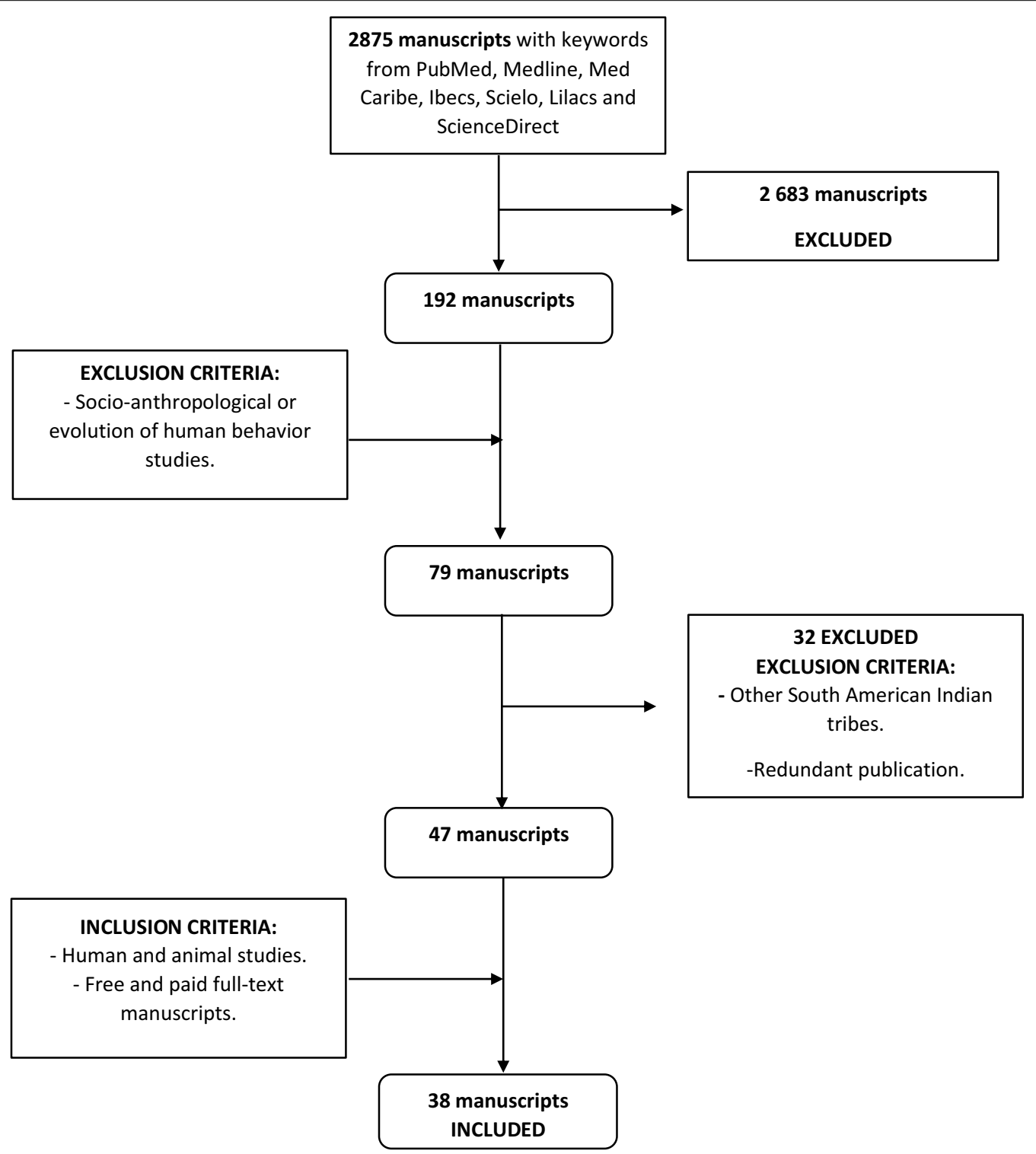

Fig. 2 PRISMA chart of the searched manuscripts 


\section{Results}

\section{Baseline characteristics}

The study consisted of 72 participants from 20 of the 47 communities, of whom 40 were men and 32 were women between 20 and 98 years, with a mean age of $57 \pm 15$ years consented for participation within this study. Of the participants, 97\% had not received any formal education, with $1.4 \%$ having completed elementary school and $1.4 \%$ completing high school. In terms of language knowledge, $63.9 \%$ of participants understood no Spanish, with the remainder of participants having $12.5 \%, 5.5 \%$ and $18.1 \%$ of beginner, intermediate and fluent levels respectively. In the baseline characteristics of the included population by sex (Table 1), there were no significant differences on age, level of education and language by sex $(\mathrm{p}>0.05)$.

\section{Survey results}

From the survey (Table 2), 65\% of the participants state that they did not sign or agree with any informed consent when approached. Nearly all (96\%) of the participants reported giving at least three blood samples for research, $29 \%$ of participants reported feeling pressured to provide samples and $75 \%$ of survey participants were given some level of explanation for blood donation. Nevertheless, participants state that $75 \%$ of these explanations were in a language other than their native tongue.

From the open-ended questions, we found that some participants were willing to provide additional information. From the 72 subjects, 33\% of recalled that the staff extracting the blood were foreigners, $56 \%$ reported that the medical personnel came from oil companies, and $17 \%$ reported being asked to provide samples by missionaries. Only 3\% of the participants recalled someone being sick when the blood extraction was conducted. The vast majority (94\%) recalled that the scientists or physicians never came back with the results of the samples or any treatments for ailments.

Most participants (75\%) were unaware that their blood would be sent abroad for further analysis, and $79 \%$ believed their rights were infringed during the experiments. Ninety-seven percent of the subjects rejected the idea their blood could be shared or commercialized in any way, by any institution, in any country.

\section{Interview results}

We interviewed 55 out of the 72 participants that were surveyed by our team (response rate $76.4 \%$ ). The team grouped the coded segments in five categories as follow:

Who was responsible for collecting the sample?

This set of themes referred to the person who led the blood sample collection. The stories included both: national and foreigners medical professionals, missionaries, and colonist related to the oil company. During the initial contact during the late 50 's, the oil companies were the only non-indigenous people in the region. They provided some "support" to the

Table 1 The relation between sex and age, level of education and Spanish level

\begin{tabular}{|c|c|c|c|c|c|c|c|c|}
\hline \multirow[t]{3}{*}{ Variables } & \multicolumn{8}{|l|}{ Sex } \\
\hline & \multicolumn{3}{|l|}{$\begin{array}{l}\text { Male } \\
n=40\end{array}$} & \multicolumn{5}{|l|}{$\begin{array}{l}\text { Female } \\
n=32\end{array}$} \\
\hline & $M \pm S D$ & $\mathbf{n}$ & $\%$ & $M \pm S D$ & $\mathbf{n}$ & $\%$ & $x^{2}$ & $\mathbf{p}$ \\
\hline Age & $58 \pm 18$ & & & $57 \pm 18$ & & & & \\
\hline$<30$ years $(n=5)$ & & 3 & 60.0 & & 2 & 40.0 & & \\
\hline $31-50(n=31)$ & & 15 & 48.4 & & 16 & 51.6 & 1.50 & 0.82 \\
\hline $51-70(n=19)$ & & 11 & 57.9 & & 8 & 42.1 & & \\
\hline $71-90(n=15)$ & & 10 & 66.7 & & 5 & 33.3 & & \\
\hline$>91$ years $(n=2)$ & & 1 & 50.0 & & 1 & 50.0 & & \\
\hline \multicolumn{9}{|l|}{ Level of education } \\
\hline Nonliterate $(n=70)$ & & 38 & 54.3 & & 32 & 45.7 & 1.64 & 0.43 \\
\hline Elementary school $(n=2)$ & & 2 & 100 & & 0 & 0 & & \\
\hline Higher education $(n=1)$ & & 1 & 100 & & 0 & 0 & & \\
\hline \multicolumn{9}{|l|}{ Spanish level } \\
\hline None $(n=46)$ & & 23 & 50.0 & & 23 & 50.0 & 2.69 & 0.44 \\
\hline Beginners $(n=9)$ & & 6 & 66.6 & & 3 & 33.3 & & \\
\hline Intermediate $(n=4)$ & & 2 & 50.0 & & 2 & 50.0 & & \\
\hline Advanced (fluent) $(n=13)$ & & 9 & 69.2 & & 4 & 30.8 & & \\
\hline
\end{tabular}


Table 2 Opened and closed questions

\begin{tabular}{|c|c|c|c|c|c|}
\hline \multirow[t]{4}{*}{ Questions } & & \multicolumn{4}{|c|}{ Sex } \\
\hline & & \multirow{2}{*}{\multicolumn{3}{|c|}{$\begin{array}{l}\text { Male } \\
n=40\end{array}$}} & \multirow{3}{*}{$\begin{array}{l}\text { Female } \\
n=32 \\
\%\end{array}$} \\
\hline & & & & & \\
\hline & & $\mathrm{n}$ & $\%$ & $\mathbf{n}$ & \\
\hline \multirow[t]{2}{*}{ Q1. Have you had blood samples taken? } & Yes & 36 & 52.9 & 32 & 47.1 \\
\hline & No & 4 & 100.0 & 0 & 0 \\
\hline \multirow[t]{5}{*}{ Q2. How many times have you taken blood samples? } & None & 3 & 100.0 & 0 & 0 \\
\hline & 1 to 2 & 29 & 52.7 & 26 & 47.3 \\
\hline & 3 to 4 & 3 & 100.0 & 0 & 0 \\
\hline & $>5$ & 1 & 33.3 & 2 & 66.7 \\
\hline & NK & 4 & 50.0 & 4 & 50.0 \\
\hline \multirow[t]{3}{*}{ Q3. Did you receive any kind of pressure or coercion for the extraction of blood samples? } & Yes & 11 & 52.4 & 10 & 47.6 \\
\hline & No & 19 & 57.6 & 14 & 42.4 \\
\hline & NK & 10 & 55.6 & 8 & 44.4 \\
\hline \multirow[t]{3}{*}{ Q4. Did they explain the purpose of this in your language? } & Yes & 29 & 53.7 & 25 & 46.3 \\
\hline & No & 9 & 56.3 & 7 & 43.8 \\
\hline & NK & 2 & 100.0 & 0 & 0 \\
\hline \multirow[t]{5}{*}{ What did you understand of the purpose? } & Some diseases & 26 & 59.1 & 18 & 40.9 \\
\hline & Medical checks & 1 & 50.0 & 1 & 50.0 \\
\hline & Hepatitis & 3 & 42.9 & 4 & 57.1 \\
\hline & Paludism & 1 & 33.3 & 2 & 66.7 \\
\hline & NK & 9 & 56.3 & 7 & 43.7 \\
\hline \multirow[t]{3}{*}{ Q5. Did you sign any type of informed consent prior to the extraction? } & Yes & 8 & 66.7 & 4 & 33.3 \\
\hline & No & 26 & 55.3 & 21 & 44.7 \\
\hline & NK & 6 & 46.2 & 7 & 53.8 \\
\hline \multirow[t]{4}{*}{ Q6. Was it national or foreign personnel that approached you for the study? } & National & 15 & 62.5 & 9 & 37.5 \\
\hline & Foreign & 11 & 45.8 & 13 & 54.2 \\
\hline & Both & 5 & 71.4 & 2 & 28.6 \\
\hline & NK & 9 & 52.9 & 8 & 47.1 \\
\hline \multirow[t]{3}{*}{ Q8. Do you know anyone who has had blood samples taken? } & Yes & 34 & 56.7 & 26 & 43.3 \\
\hline & No & 0 & 0.0 & 0 & 0.0 \\
\hline & NK & 6 & 50.0 & 6 & 50.0 \\
\hline \multirow[t]{3}{*}{ Q10. Were there sick people in your community at the time of? } & Yes & 1 & 50.0 & 1 & 50.0 \\
\hline & No & 18 & 56.3 & 14 & 43.8 \\
\hline & NK & 21 & 55.3 & 17 & 44.7 \\
\hline \multirow[t]{3}{*}{ Q11. Did the physicians return to perform some type of treatment related to the samples? } & Yes & 0 & 0.0 & 0 & 0.0 \\
\hline & No & 38 & 55.9 & 30 & 44.1 \\
\hline & NK & 2 & 50.0 & 2 & 50.0 \\
\hline \multirow[t]{3}{*}{ Q12. Did they tell you that the samples were going to be moved out of Ecuador? } & Yes & 8 & 61.5 & 5 & 38.5 \\
\hline & No & 28 & 51.9 & 26 & 48.1 \\
\hline & NK & 4 & 80.0 & 1 & 20.0 \\
\hline \multirow[t]{3}{*}{ Q13. Would you agree that your blood or a product of it is marketed by third parties? } & Yes & 0 & 0 & 0 & 0 \\
\hline & No & 38 & 54.3 & 32 & 45.7 \\
\hline & NK & 2 & 100.0 & 0 & 0 \\
\hline \multirow[t]{3}{*}{ Q14. Do you think your rights were affected in any way? } & Yes & 31 & 54.4 & 26 & 45.6 \\
\hline & No & 0 & 0.0 & 0 & 0.0 \\
\hline & NK & 9 & 60.0 & 6 & 40.0 \\
\hline
\end{tabular}


indigenous communities in terms of medical attention and education.

In this category, 46 quotes were identified including some of the following examples, with the responses given in Wao-Terero translated to Spanish, then English:

"The physicians that came to the community were from Ecuador and from other places, they used Dayuma to translate between us." Case \#\#03, Age group 71-90 yrs.

"Someone translated, it was the Americans themselves who learned the language at the summer language institute (IVL), so they can study us." Case \#02, Age group 51-70 yrs.

How many times your blood was drawn?

The domain in which the Waorani reported how many times they have given blood has shown that on average, the community members have experienced three blood extractions for research purposes in the last 40 years. This domain was found in 7 occasions and included testimonies like this:

"Our blood was extracted at least two times. The first one around 1984 and a second time in 1991, with help of the missionaries." Case \#\#04, Age group 51-70 yrs.

\section{Voluntariness of the extraction}

This category referred to freedom in the decisionmaking process when natives gave their blood. The pressure or coercion arose from the entire community and from the research team. All cases reflect that they never signed any paper giving their consent either for the purpose mentioned or for other studies outside the country. The burden imposed on the tribe to offer the blood had nine quotes, including testimonies like the following:

"We were concentrated in the Teweno Community [a community created by the missionaries and used as an indoctrination centre for the Waorani in the process of evangelization] with more than 100 other Waorani, more than 20 years ago, where we were allocated for the study" Case \#\#50 Age group 51-70 yrs.

"They told us that the doctors who were going to draw the blood came to our communities to see if we have Hepatitis $A, B$ and $C$ diseases. They took family by family. My daddy did not want to give blood, but the brother said yes, that he should go because it is a very serious illness and he could die" Case \#\#19, Age group 51-70 yrs.

Communication used during the studies:
This category ranges from the language they used (Spanish or English instead of Wao-Terero) to the understanding of the commands that were given. The analysis of the interviews reflects that in some cases, the team leaders did translate part of the information to be given while in other cases, they did not.

"We were moved in addition to other families towards the community of Teweno. The translator was not happy. We had some trouble with it." Case \#\#02, Age group 71-90 yrs.

According to the Waorani, the understanding of the purpose for the visits was to see if their blood was good or bad, or to check for diseases in order to perform new treatments. No further information was given on the purpose of the studies.

Returning with the results and final destination of the samples:

This category reflects that researchers told the Waorani they will return to their communities with the results, nevertheless, in very few occasions they did but, in most cases, the Waorani reported they never came back.

"When extracting the blood, they did not give us any information. We were transferred to Teweno, with the help of the missionaries" Case \#\#06, age unknown, estimated between 80-100 yrs.

The Waorani state they did not know about the future of their blood, nor about the possibility of commercializing it for any economic value.

"I knew they were going to investigate our diseases. Nevertheless, they never told me they were going to take the samples abroad. I did not agree with that, with selling the samples, we are human, I feel hurt, I didn't agree with that" Case \#\#57, age group 51-75 yrs.

"No, they never came back, once they left, they never came back" Case \#\#57, age group 71-90 yrs.

\section{Use of samples for research}

From our search, thirty-eight studies were identified to have carried out research on the Waorani population. A greater number of studies were carried out by international institutes, mostly by United States of America (USA) $(\mathrm{n}=18 ; 47.4 \%)$, followed by European countries $(n=13 ; 34.2 \%)$, countries of Central and South America $(\mathrm{n}=6 ; 15.8 \%)$ and Japan $(\mathrm{n}=1 ; 2.6 \%)$ (Table 3).

Eighty-nine percent of the published studies used Waorani blood samples 2,844 times between 1978-2016. Twenty-three percent of the studies reported obtaining genetic samples. The majority of the studies (84\%) included authors from outside of Ecuador. Seventy-one 


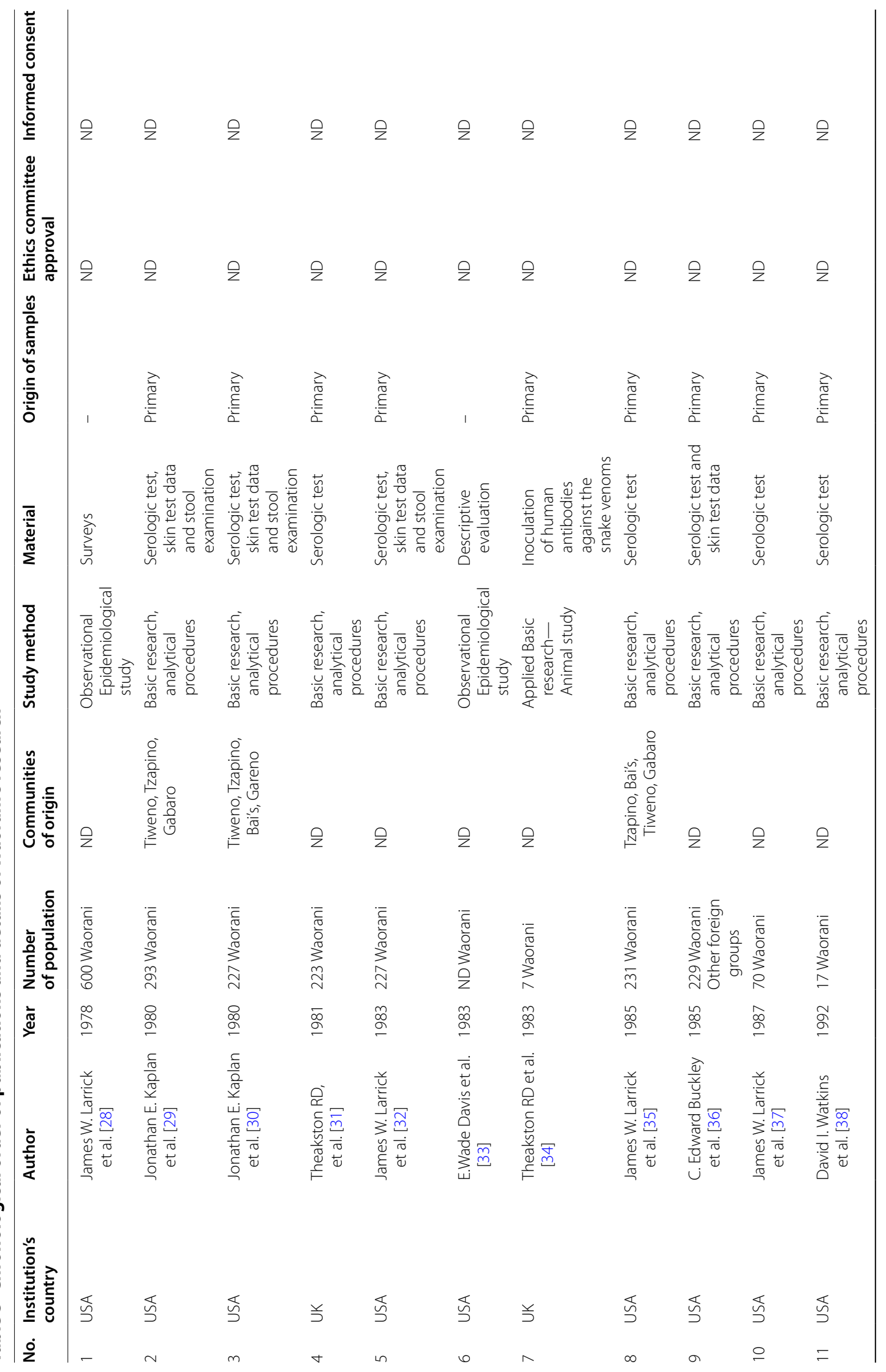




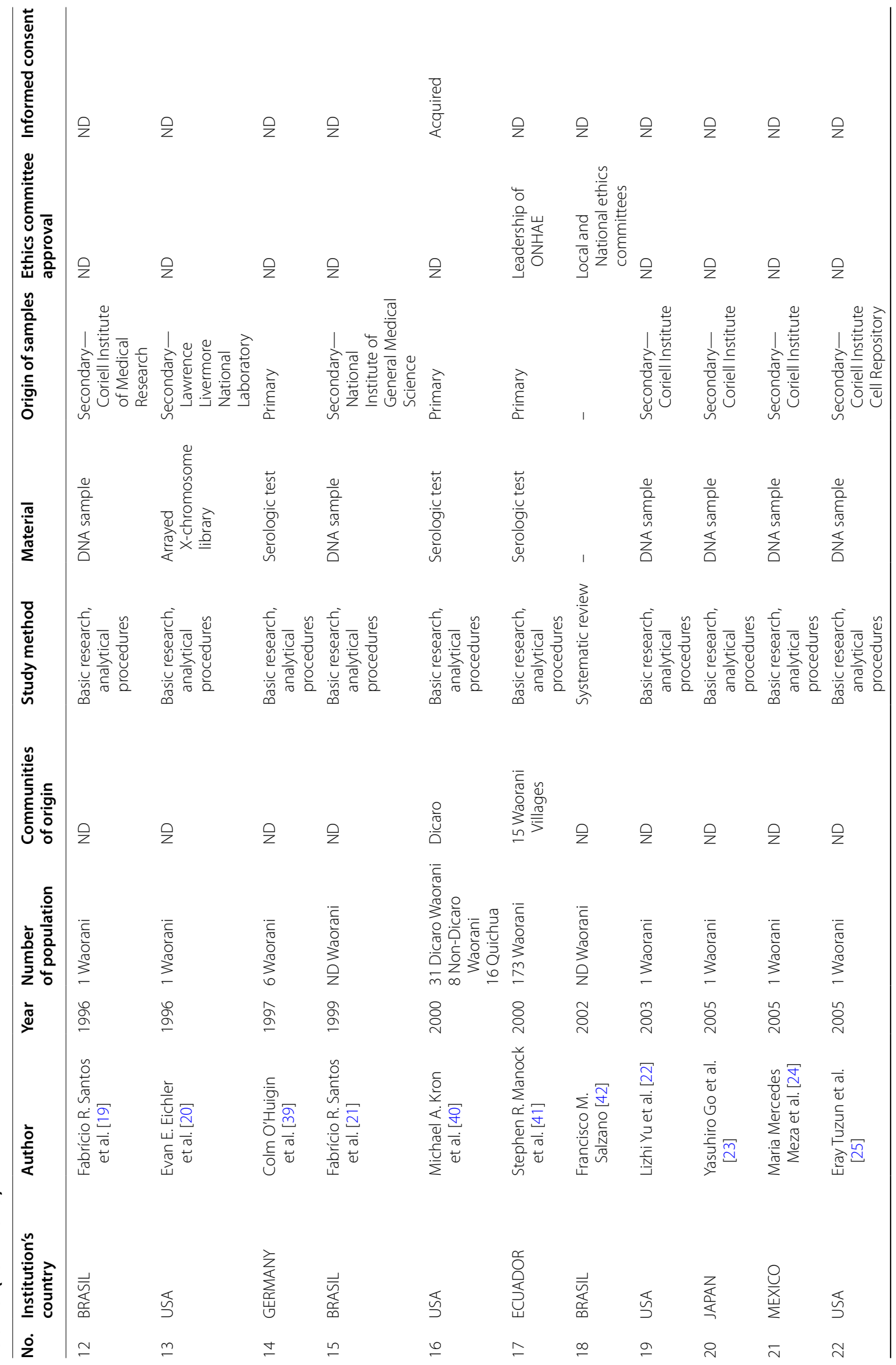




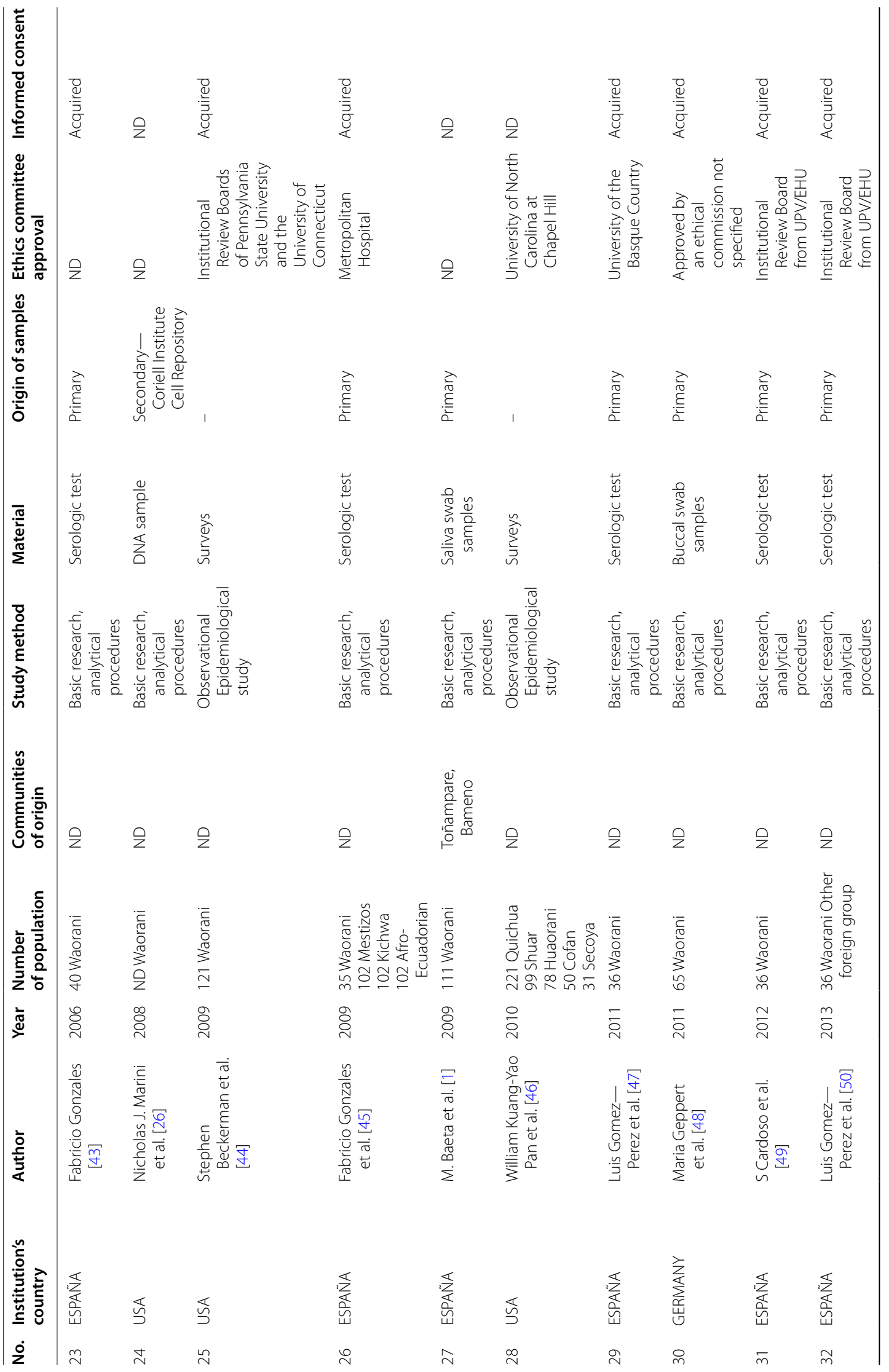




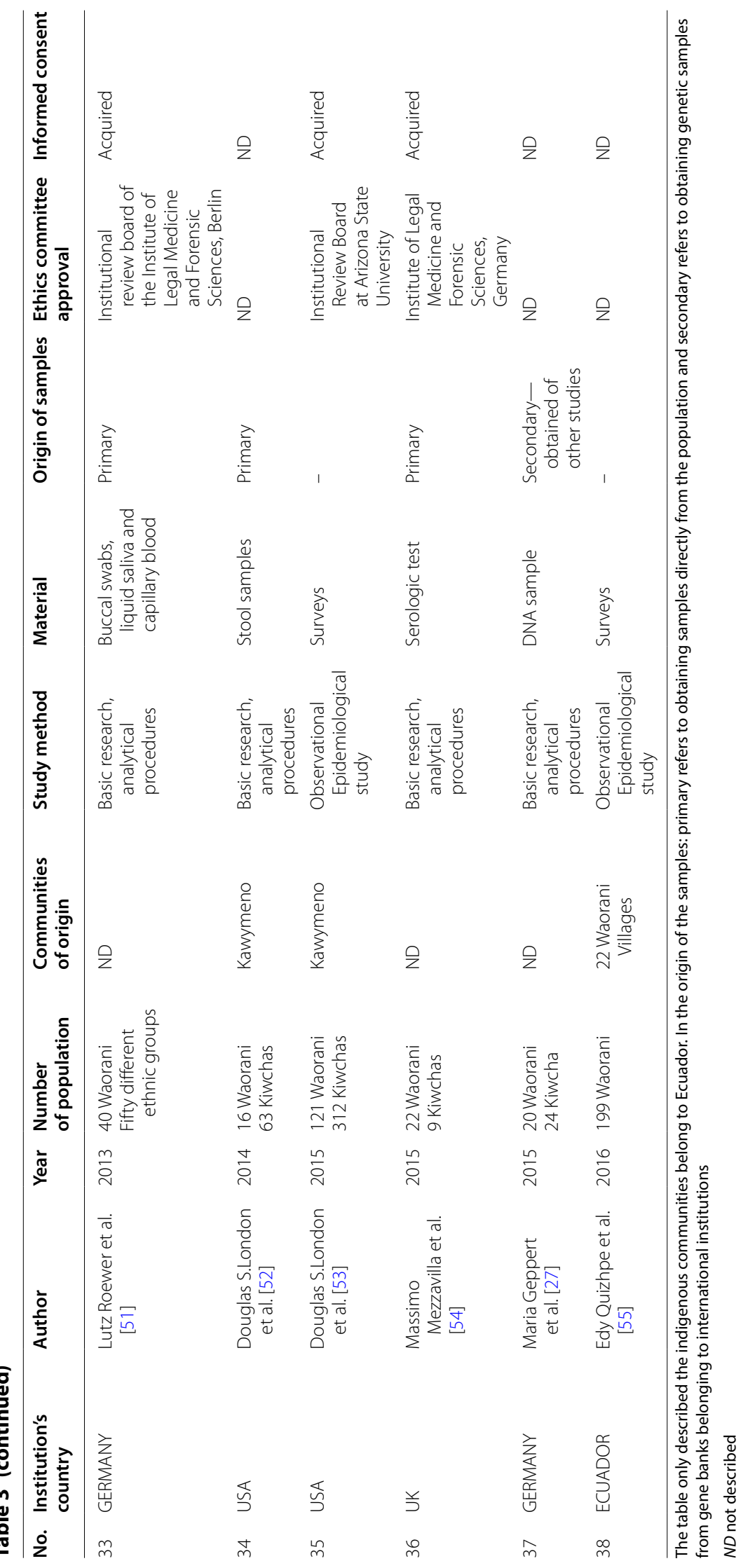


percent of the studies used samples directly from the population $(71 \%)$ for research after being collected, and $29 \%$ of the samples were obtained from biorepositories. The majority of the studies (68\%) did not report obtaining research ethics board approval and $71 \%$ did not report obtaining the informed consent of the participants prior to the execution of the project.

Basic research studies aimed to analyze biological samples such as serologic test, skin test data and stool examination. The origin of the samples is classified into two types: primary, those that were obtained directly from the population $(n=22 ; 71 \%)$; and, secondary $(n=9$; $29 \%$ ) that were obtained from gene banks belonging to international institutions such as Coriell Institute, Lawrence Livermore National Laboratory, National Institute of General Medical Sciences or genetic samples obtained from other studies [19-27].

It is evident that the majority of the studies did not mention to get an informed consent of the participants before the commencement of the project $(n=27$; $71.0 \%)$, neither ethics committee approval national nor international $(\mathrm{n}=26 ; 68.4 \%)$.

\section{Discussion}

This study reports the potential ethical violations from previous studies conducted on the Waorani natives in Ecuador. Based on the triangulation of the three sources of information collected in this study (literature review, survey and interviews) is clear that the Waorani tribe was not fully informed about the purpose of most of the studies, nor where the biological samples would end up.

Our study identified three major ethical violations, lack of informed consent, coercion and lack of return of results. The study documents among Waorani community members, with limited contact with what is known as "civilization", who had blood samples taken without a fully informed consent process or documentation. It was reported that there was coercion by foreign staff from oil companies and missionaries for participation within studies and that there was a lack of return of results to the tribe, with samples reused for clinical research by foreign and national investigators. The strengths of this study include the mixed methods approach, which included structured face-to-face interviews with locals in their most comfortable language preference and the literature review of previous reports involving Waorani biological material.

The isolation of the Waorani tribes has made them highly coveted among scientists because of their unique genetic profiles and the lack of any human subject protection programs in the Ecuadorian state. Globally, indigenous people are underrepresented in genomic research studies for a variety of reasons including failure to engage indigenous communities in ethical and inclusive ways, lack of study transparency, and historical and recent research malpractice. These have sowed mistrust and justified peoples' unwillingness to share personal health information, including DNA, with the wider research community. Examples of research that involved large scale research misconduct and ethical violations include the Human Genome Diversity Project (HGDP) and the subsequent National Genographic Project. These projects began as endeavors to study worldwide human genetic diversity and global migration patterns, however, these projects failed to fully consider the damaging social and political implications to Indigenous communities. In the case of the HGDP, the project prompted strong resistance by the Indigenous Peoples' Council on Bio-colonialism and tarnished future trust in research and researchers [57]. The Havasupai Tribe filed a lawsuit against the Arizona Board of Regents over lack of informed consent and a violation of civil rights in addition to unapproved genetic research with DNA samples in prior research also. The case raised awareness of cultural and political sensitivities around what constitutes appropriate research [58]. These examples have raised concerns about the negative impacts that research harms (e.g., stigmatization, violation of individuals' rights, lack of benefit, and cultural incongruence) can have on Indigenous communities.

Potential explanations for our results include, firstly, within the timeframe when the initial publications were submitted, journals were not enforcing reporting research ethics board approval or informed consent use. The legal requirements required before obtaining a clinical research permit has changed in the last 50 years, however some basic precepts would seem that they have not been met. On the other hand, it is important to understand that at that time, Ecuador, lacked bioethical regulations and this could explain in part some of the scarcities in the revised investigations. At the same time, although it was evident that regarding human rights' principles applied to medical investigations, some deficiencies were found, during the time of some of those investigations, The Belmont report, a US government commission document was not legally binding in the US, therefore not applicable to other parts of the world.

Second, poor communication abilities might cause that research brigades were offered as medical interventions, while in fact they were always intended to obtain biomedical data. Third, national and international scientists obtained blood samples from vulnerable populations and used it for research and commercial purposes. 
The lack of evidence of proper ethical conduct in most of the published manuscripts and the lack of IRB permits including the informed consent process is worrisome. These flaws from the bioethical point of view are particularly important because indigenous populations are highly vulnerable due to several factors including poverty and high rates of illiteracy.

As local researchers, we found those practices are using a colonialist model, a visible practices found in developing and underrepresented populations through scientific malpractices [59]. According to the reflections of Restrepo \& Rojas on the decolonial inflection, the coloniality of power can be said as the way to produce knowledge from a colonial model implies a place of power, exploitation and conflict [60]. From an expert position, foreign researchers and with the collaboration of Ecuadorians sold a health problem to the Waorani communities, used them to generate their scientific products without respecting the ethical parameters that they had in their societies [60].

There is a general ethical requirement that prospective participants in research give their voluntary consent to participate. Introducing coercion into this process breaks a critical step by affecting the voluntariness of consent and provides no reasonable alternative [61]. Coercion and undue influence has been a topic of recent attention when discussing payment to research participants since in most South American countries contrary to the United States, payment for research participation is not allowed [62]. However, in this case coercion was a threat rather than an inducement. During interviews, acts of coercion and the lack of informed consent were highlighted by some individuals in the Waorani communities. It was particularly troubling to hear that some community members felt healthcare personnel exerted pressure for everyone to provide blood samples and then never to return with the results of the exams or with treatments for ailments. This strengthens the theory that the reason for the blood draw was scientific, and not to treat any disease.

Another important result that deserves comment is the lack of return of results to research participants. With the recent changes to the common rule in the United States there has been a push to including some of this language in the informed consent in an effort to spark the conversation during the informed consent process. At the same time the majority of study participants will not only want to obtain results that are actionable but receiving all results. In this case, results were never returned.

One of the strengths of this study is the use of mixed methods, since it crosses the information of the scientific products with the testimonies, exploring the beliefs and perceptions of the same sample.

\section{Limitations}

This study was not exempt from limitations. Many samples were taken several years ago and recall bias from the participants could have influenced our results. The lack of reporting of research ethics board approval in previous studies could be due to having no requirement to disclose this information at the time of publication. The translation of Wao-Terero to Spanish to English may also cause inaccuracies; however it was felt that this was a small limitation due to the review of the statements made by the participants by fluent WaoTerero/Spanish speakers. These were subsequently translated into English, which was reviewed by fluent English speakers.

The content analysis was performed manually since no coding software was available at the time of the data collection. In this sense, we did not perform an interrater concordance test while reviewing the testimonies, instead we evaluate disagreement between items.

Recently, due to prior ethics violations on indigenous populations, a framework for research involving such communities has been proposed. The framework includes six principles when engaging in ethical research with indigenous people. The principles include understanding tribal sovereignty and research regulation, engaging and collaborating with tribal community, build cultural competency, improve the transparency of research practices, build tribal research capacity, disseminate findings in a community accessible format.

\section{Conclusions}

We have documented for the first time the experiences and perceptions of indigenous vulnerable Waorani community members in the Amazonian region of Ecuador, about being approached by foreign and national scientists for the obtention of biological material. Upon interview and analysis of questionnaire results, several themes were highlighted, which included the negative experience the community members had with researchers, and the lack of a rigorous ethical research approach that the investigators presented. Clinical Research on the Waorani community in the Ecuadorian Amazon basin has been performed on several occasions. Unfortunately, the majority of these projects did not follow the appropriate ethical and professional standards in either reporting the results or fulfilling them. The results described that the lack of information concerning the approval of study, ensuring that participants understood the purpose of their samples being drawn was not correct. Although local regulations were lacking during the time of the study, international treaties, agreements and declarations 
were available worldwide, but not fulfilled by the majority of researchers involved in this study.

Although the government of Ecuador tried to further inspect some of these human rights violations, the investigations did not progress in courts. In this sense, this study aims to contribute to enhancing the awareness of unethical practices the occurred in Ecuador during the last 40 decades. Understanding the insights of this type of situations from a near-isolated communities in Ecuador, involving their experiences in previous medical research is a unique opportunity to raise conscience among the scientific community.

\section{Supplementary information}

Supplementary information accompanies this paper at https://doi. org/10.1186/s12910-020-00542-x.

Additional file 1. 15-item questionnaire.

\section{Abbreviations}

HGDP: Human Genome Diversity Project; NAWE: Nacionalidad Waorani del Ecuador; ND: Not described; USA: United States of America; IVL: Summer Language Institute.

\section{Acknowledgements}

The authors wish to thank the Waorani communities and their leaders who agreed to participate in this study. The authors also wish to thank everyone involved in the design and research of this project, including the Ministry of Science and Technology, those responsible for the logistics involved in reaching the communities, and the translators as without them the project would not have been possible.

\section{Authors' contributions}

EO was the principal investigator and the corresponding author for this study. EO managed the research group and was responsible for liaising with representatives of the NAWE for the approval of the study. JB was the communication lead and managed the organisation of translation for the study. AN was the field study expert for the investigation, and $M C$ acted as the lawyer and ethics consultant for the investigation. KSR, LGB, LT, JCB, LAD and $A L$ were responsible for the data analysis, coding and the writing of the final manuscript. All authors read and approved the final manuscript.

\section{Funding}

This study was fully funded by The Minister of Science and Technology (Senescyt) after obtaining approval from the former president of Ecuador, Rafael Correa Delgado. The funding body neither their authorities had any role designing, analysing, interpreting or interfering in any way within this project.

\section{Availability of data and materials}

The datasets used and analysed during the current study are available from the corresponding author on reasonable request.

\section{Ethics approval and consent to participate}

This study received ethical approval from Senescyt in 2012. All the Participants in this study gave signed informed consent for participation and were asked to verify in their native tongue that they understood the study design and were happy to proceed with participation.

\section{Consent for publication}

The authors of this study were all in agreeance for publication of this study, and the participants involved approved the participation in the distribution of the results.

\section{Competing interests}

The authors declare no conflicts of interest.

\section{Author details}

${ }^{1}$ One Health Research Group, Faculty of Medicine, Universidad de Las Americas, Ecuador Calle de los Colimes y Avenida De los Granados, Quito 170137, Ecuador. ${ }^{2}$ Division of Population Health and Computational Medicine, University of Miami, Florida, USA. ${ }^{3}$ Public Health Program, Faculty of Medicine, University of Southampton, Southampton, England. ${ }^{4}$ Grassland Group, Technical University of Munich, Munich, Germany. ${ }^{5}$ Ministerio de Biodiversidad, Quito, Ecuador. ${ }^{6}$ Faculty of Psychology, Universidad de Las Americas, Quito, Ecuador.

Received: 31 December 2019 Accepted: 6 October 2020

Published online: 17 October 2020

References

1. Baeta M, Núñez C, González-Andrade F, Sosa C, Casalod Y, Bolea M, et al. Mitochondrial analysis revealed high homogeneity in the Waorani population - the last nomadic group of hunter-gatherers from Ecuador. Forensic Sci Int Genet Suppl Ser. 2009;2:313-4.

2. Pringle $\mathrm{H}$. Uncontacted tribe in Brazil emerges from isolation. American Association for the Advancement of Science; 2014.

3. Feather C. Isolated tribes: contact misguided. Science. 2015;349:798-798

4. Bodley JH. Isolated tribes: human rights first. Science. 2015;349:798-9.

5. Fitzpatrick EF, Martiniuk AL, D'Antoine H, Oscar J, Carter M, Elliott EJ. Seeking consent for research with indigenous communities: a systematic review. BMC Med Ethics. 2016:17:65.

6. Guillemin M, Gillam L, Barnard E, Stewart P, Walker H, Rosenthal D. "We're checking them out": indigenous and non-Indigenous research participants' accounts of deciding to be involved in research. Int J Equity Health. 2016;15:8.

7. Hurley DA, Kostelecky SR, Aguilar P. Whose knowledge? Representing Indigenous realities in library and archival collections. Milton Park: Taylor \& Francis; 2017.

8. Nugent S. The Yanomami: anthropological discourse and ethics. In: The ethics of anthropology. Routledge; 2004. p. 91-109.

9. Sponsel LE. Yanomami: an arena of conflict and aggression in the Amazon. Aggress Behav. 1998;24:97-122.

10. Castellano MB. Ethics of Aboriginal research. Global bioethics and human rights: contemporary issues. 2014:273

11. Harding A, Harper B, Stone D, O'Neill C, Berger P, Harris S, et al. Conducting research with tribal communities: sovereignty, ethics, and data-sharing issues. Environ Health Perspect. 2011;120:6-10.

12. Kelley A, Belcourt-Dittloff A, Belcourt C, Belcourt G. Research ethics and indigenous communities. Am J Public Health. 2013;103:2146-52.

13. Nowrouzi B, McGregor L, McDougall A, Debassige D, Casole J, Nguyen C, et al. Ethics of biological sampling research with aboriginal communities in Canada. Glob J Health Sci. 2017;9.

14. Gonzáles Amaya MG. Implicaciones jurídicas: Biotecnología y la colecta inconsulta del ADN en los Pueblos y Nacionalidades del Ecuador. B.S. thesis. Quito: UCE; 2016

15. Fernández CF. El análisis de contenidocomoayudametodológica para la investigación. Rev Cienc Soc Cr. 2002;1l:35-53.

16. Hernández Sampieri R, Fernández Collado C, Baptista Lucio P. Metodología De La Investigación Semblanza De Los Autores. 2004; 533.

17. Ritchie J, Lewis J, Nicholls CM, Ormston R. Qualitative research practice: a guide for social science students and researchers. $2^{\mathrm{a}}$. London: SAGE Publications, Inc:; 2013.

18. Creswell JW. Research design: Qualitative, quantitative, and mixed methods approaches. Sage Publications; 2013. https ://books.google.com/books?hl=en\&lr=\&id=EbogAQAAQB AJ\&oi $=$ fnd \&pg $=P R 1 \& d q=$ qualitative + quantitative + resea rch\&ots $=$ cafQtPOCD4\&sig=QQkyjAUv6BstmOkwgM4fOPpxdnl. Accessed 26 Feb 2016.

19. Santos FR, Gerelsaikhan T, Munkhtuja B, Oyunsuren T, Epplen JT, Pena SD. Geographic differences in the allele frequencies of the human Y-linked tetranucleotide polymorphism DYS19. Hum Genet. 1996;97:309-13. 
20. Eichler EE, Lu F, Shen Y, Antonacci R, Jurecic V, Doggett NA, et al. Duplication of a gene-rich cluster between 16p11.1 and Xq28: a novel pericentromeric-directed mechanism for paralogous genome evolution. Hum Mol Genet. 1996;5:899-912.

21. Santos FR, Pandya A, Tyler-Smith C, Pena SD, Schanfield M, Leonard WR, et al. The central Siberian origin for native American $Y$ chromosomes. Am J Hum Genet. 1999;64:619-28.

22. Yu L, Kalla K, Guthrie E, Vidrine A, Klimecki WT. Genetic variation in genes associated with arsenic metabolism: glutathione S-transferase omega 1-1 and purine nucleoside phosphorylase polymorphisms in European and indigenous Americans. Environ Health Perspect. 2003;111:1421-7.

23. Go Y, Satta Y, Takenaka O, Takahata N. Lineage-specific loss of function of bitter taste receptor genes in humans and nonhuman primates. Genetics. 2005;170:313-26.

24. Meza MM, Yu L, Rodriguez YY, Guild M, Thompson D, Gandolfi AJ, et al. Developmentally restricted genetic determinants of human arsenic metabolism: association between urinary methylated arsenic and CYT19 polymorphisms in children. Environ Health Perspect. 2005;113:775-81.

25. Tuzun E, Sharp AJ, Bailey JA, Kaul R, Morrison VA, Pertz LM, et al. Fine-scale structural variation of the human genome. Nat Genet. 2005;37:727-32.

26. Marini NJ, Gin J, Ziegle J, Keho KH, Ginzinger D, Gilbert DA, et al. The prevalence of folate-remedial MTHFR enzyme variants in humans. Proc Natl Acad Sci USA. 2008;105:8055-60.

27. Geppert M, Ayub Q, Xue Y, Santos S, Ribeiro-dos-Santos Â, Baeta M, et al. Identification of new SNPs in native South American populations by resequencing the Y chromosome. Forensic Scilnt Genet. 2015;15:111-4.

28. Larrick JW, Yost JA, Kaplan J. Snake bite among the Waorani Indians of eastern Ecuador. Trans R Soc Trop Med Hyg. 1978;72:542-3.

29. Kaplan JE, Larrick JW, Yost JA. Hyperimmunoglobulinemia E in the Waorani, an isolated Amerindian population. Am J Trop Med Hyg. 1980;29:1012-7.

30. Kaplan JE, Larrick JW, Yost J, Farrell L, Greenberg HB, Herrmann KL, et al. Infectious disease patterns in the Waorani, an isolated Amerindian population. Am J Trop Med Hyg. 1980;29:298-312.

31. Theakston RD, Reid HA, Larrick JW, Kaplan J, Yost JA. Snake venom antibodies in Ecuadorian Indians. J Trop Med Hyg. 1981;84:199-202.

32. Larrick JW, Buckley CE III, Machamer CE, Schlagel GD, Yost JA, BlessingMoore J, et al. Does hyperimmunoglobulinemia-E protect tropical populations from allergic disease? J Allergy Clinlmmunol. 1983;71:184-8.

33. Davis EW, Yost JA. Theethnomedicine of the Waorani of Amazonian Ecuador. J Ethnopharmacol. 1983;9:273-97.

34. Theakston RDG. The application of immunoassay techniques, including enzyme-linked immunosorbent assay (ELISA), to snake venom research. Toxicon. 1983:21:341-52.

35. Larrick JW, Yost J, Gourley C, Buckley CE, Plato CC, Pandey JP, et al. Markers of genetic variation among the Waorani Indians of the Ecuadorian Amazon headwaters. Am J PhysAnthropol. 1985;66:445-53.

36. Buckley CE III, Larrick JW, Kaplan JE. Population differences in cutaneous methacholine reactivity and circulating IgE concentrations. J Allergy Clinlmmunol. 1985;76:847-54

37. Larrick JW, Schable C, Kaplan JE. HIV infection in Waorani Indians of eastern Ecuador. Trans R Soc Trop Med Hyg. 1987;81:173.

38. Watkins DI, McAdam SN, Liu X, Strang CR, Milford EL, Levine CG, et al. New recombinant HLA-B alleles in a tribe of South American Amerindians indicate rapid evolution of MHC class I loci. Nature. 1992;357:329-33.

39. Brady JE. Huaorani tribe of ecuador: a study in self-determination for indigenous peoples. Harv Hum Rights J. 1997;10:291.

40. Kron MA, Ammunariz M, Pandey J, Guzman JR Hyperimmunoglobulinemia $E$ in the absence of atopy and filarial infection: the Huaorani of Ecuador. In: Allergy and asthma proceedings. OceanSide Publications, Inc; 2000. p. 335-341. https://www.ingentacon nect.com/content/ocean/aap/2000/00000021/00000006/art00001. Accessed 30 Mar 2014.

41. Manock SR, Kelley PM, Hyams KC, Douce R, Smalligan RD, Watts DM, et al. An outbreak of fulminant hepatitis delta in the Waorani, an indigenous people of the Amazon basin of Ecuador. Am J Trop Med Hyg. 2000;63:209-13.

42. Salzano FM. Molecular variability in Amerindians: widespread but uneven information. An Acad Bras Ciênc. 2002;74:223-63.
43. González-Andrade F. Análisis molecular de variación de polimorfismos STR autosómicos y de cromosoma "Y" en grupos étnicos de Ecuador con aplicación médico-forense. Mem Tesis Dr En Med Esp Univ Zaragoza. 2006.

44. Beckerman S, Erickson PI, Yost J, Regalado J, Jaramillo L, Sparks C, et al. Life histories, blood revenge, and reproductive success among the Waorani of Ecuador. Proc Natl Acad Sci. 2009;106:8134-9.

45. Gonzalez-Andrade F, Roewer L, Willuweit S, Sanchez D, Martínez-Jarreta B. Y-STR variation among ethnic groups from Ecuador: Mestizos, Kichwas, Afro-Ecuadorians and Waoranis. Forensic Scilnt Genet. 2009;3:e83-91.

46. Kuang-Yao Pan W, Erlien C, Bilsborrow RE. Morbidity and mortality disparities among colonist and indigenous populations in the Ecuadorian Amazon. Soc Sci Med. 2010;70:401-11.

47. Gómez-Pérez L, Alfonso-Sánchez MA, Sánchez D, García-Obregón S, Espinosa I, Martínez-Jarreta B, et al. Alu polymorphisms in the Waorani tribe from the Ecuadorian Amazon reflect the effects of isolation and genetic drift. Am J Hum Biol. 2011;23:790-5.

48. Geppert M, Baeta M, Núñez C, Martínez-Jarreta B, Zweynert S, Cruz OWV, et al. Hierarchical Y-SNP assay to study the hidden diversity and phylogenetic relationship of native populations in South America. Forensic Scilnt Genet. 2011;5:100-4.

49. Cardoso S, Alfonso-Sánchez MA, Valverde L, Sánchez D, Zarrabeitia MT, Odriozola A, et al. Genetic uniqueness of the Waorani tribe from the Ecuadorian Amazon. Heredity. 2012;108:609.

50. Gómez-Pérez L, Alfonso-Sánchez MA, Dipierri JE, Sánchez D, Espinosa I, De Pancorbo MM, et al. Young Alu insertions within the MHC class I region in native American populations: Insights into the origin of the MHC-Alu repeats. Am J Hum Biol. 2013;25:359-65.

51. Roewer L, Nothnagel M, Gusmão L, Gomes V, González M, Corach D, et al. Continent-wide decoupling of Y-chromosomal genetic variation from language and geography in native South Americans. PLoS Genet. 2013;9:e1003460

52. London D, Hruschka D. Helminths and human ancestral immune ecology: What is the evidence for high helminth loads among foragers? Am J Hum Biol. 2014;26:124-9.

53. London DS, Beezhold B. A phytochemical-rich diet may explain the absence of age-related decline in visual acuity of Amazonian huntergatherers in Ecuador. Nutr Res. 2015;35:107-17.

54. Mezzavilla M, Geppert M, Tyler-Smith C, Roewer L, Xue Y. Insights into the origin of rare haplogroup $\mathrm{C} 3^{*} \mathrm{Y}$ chromosomes in South America from high-density autosomal SNP genotyping. Forensic Scilnt Genet. 2015;15:115-20.

55. Quizhpe E, Ñauta G, Córdoba-Doña JA, Teran E. Five-year eradication of hepatitis $b$ infection after an outreach immunization program in the waorani population in the ecuadorian amazon. Am J Trop Med Hyg. 2016;95:670-3.

56. Belich MP, Madrigal JA, Hildebrand WH, Zemmour J, Williams RC, Luz $R$, et al. Unusual HLA-B alleles in two tribes of Brazilian Indians. Nature. 1992;357:326-9.

57. Dodson M, Williamson R. Indigenous peoples and the morality of the Human Genome Diversity Project. J Med Ethics. 1999;25:204-8.

58. Mello MM, Wolf LE. The Havasupai Indian tribe case-lessons for research involving stored biologic samples. N Engl J Med. 2010;363:204-7.

59. Orellano C, Gonzalez S. Acerca de la opcióndecolonial en el ámbito de la psicología. Perspect En Psicol. 2015;12:1-8.

60. Valencia JC. Eduardo Restrepo y Axel Rojas, Inflexión decolonial. Popayán, Colombia, Universidad del Cauca, Instituto Pensar, Universidad Javeriana, 2010, 234 pp. Am Mém Identités Territ. 2012.

61. Tamariz L, Kirolos I, Pendola F, Marcus EN, Carrasquillo O, Rivadeneira J, et al. Minority veterans are more willing to participate in complex studies compared to non-minorities. J Bioethical Inq. 2018;15:155-61.

62. Largent EA, Lynch HF. Paying research participants: The outsized influence of "undue influence." IRB. 2017;39:1.

\section{Publisher's Note}

Springer Nature remains neutral with regard to jurisdictional claims in published maps and institutional affiliations. 